\title{
UJI TOKSISITAS AKUT EKSTRAK ETANOL DAUN TUMBUHAN AKAR KAIK-KAIK (Uncaria cordata (Lour) Merr) TERHADAP MENCIT PUTIH JANTAN (Mus musculus L)
}

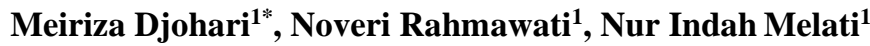 \\ ${ }^{1}$ Sekolah Tinggi Ilmu Farmasi Riau; Jl.Kamboja, Simpang Baru, Kec. Tampan, Kota Pekanbaru, Riau 28289, telp (0761) 588007 \\ Email: meirizadj@stifar-riau.ac.id
}

\begin{abstract}
ABSTRAK
Telah dilakukan penelitian tentang uji toksisitas akut ekstrak etanol daun tumbuhan akar kaik-kaik (Uncaria cordata (Lour) Merr) pada mencit putih (Mus musculus L.) jantan. Penelitian ini bertujuan untuk mengetahui efek toksisitas akut dan tertunda dari ekstrak etanol daun tumbuhan akar kaik-kaik (Uncaria cordata (Lour) Merr) melalui penentuan nilai LD $_{50}$. Hewan percobaan dibagi menjadi 4 kelompok, yaitu kelompok kontrol negatif (NaCMC), dan kelompok ekstrak etanol daun tumbuhan akar kaik-kaik dengan dosis 200, 1000, dan 5000 mg/KgBB. Hasil penelitian menunjukkan bahwa nilai $\mathrm{LD}_{50}>5000 \mathrm{mg} / \mathrm{kg}$ BB dan termasuk kedalam kategori praktis tidak toksik. Pada pengamatan tidak terjadi adanya tremor, kejang, salivasi, diare, letargi, lemah, tidur, dan koma pada setiap hewan percobaan.
\end{abstract}

Kata kunci : Ekstrak etanol daun tumbuhan akar kaik-kaik, nilai $\mathrm{LD}_{50}$

\section{ABSTRACT}

Research on the acute toxicity test of the ethanol extract of kaik-kaik (Uncaria cordata (Lour) Merr) leaves has been carried out on male white mice (Mus musculus L.). This study aims to determine the effects of acute and delayed toxicity of the ethanol extract of akar kaik- kaik (Uncaria cordata (Lour) Merr) leaves by determining the $\mathrm{LD}_{50}$ value. The experimental animals were divided into 4 groups, namely the negative control group (NaCMC), and the ethanol extract group of kaik-kaik root leaves with doses of 200, 1000, and $5000 \mathrm{mg} / \mathrm{KgBW}$. The results showed that the $\mathrm{LD}_{50}$ value was> $5000 \mathrm{mg} / \mathrm{kgBW}$ and was included in the practical non-toxic category. In the observation, there were no tremors, seizures, salivation, diarrhea, lethargy, weakness, sleep, and coma in each experimental animal.

\section{PENDAHULUAN}

Indonesia merupakan salah satu negara penghasil tanaman obat yang potensial dengan keanekaragaman yang dimilikinya. Di hutan tropis Indonesia tumbuh sekitar 30.000 spesies tumbuhan berbunga dan diperkirakan sekitar 3.689 spesies diantaranya merupakan tumbuhan obat (Djauhariya dan Hermani, 2004).

Salah satu tanaman obat yang digunakan masyarakat di beberapa negara tropis adalah tumbuhan genus Uncaria. Sebagian besar tanaman dari genus Uncaria telah digunakan sebagai sumber bahan obat alam tradisonal. Banyak spesies dari genus Uncaria telah digunakan mengobati spasmolitik, nyeri, hipertensi, kanker, arthiritis, diabetes, antioksidan dan inflamasi (Ernawati, 2004).

Salah satu spesies dari genus Uncaria yang belum banyak dipublikasikan adalah Uncaria cordata (Lour) Merr. Adapun penelitian terhadap genus Uncaria cordata (Lour) Merr yang telah dilakukan sebelumnya, yaitu ekstrak metanol yang memiliki aktivitas antioksidan yang sangat kuat dengan $\mathrm{IC}_{50}$ sebesar 6,778 $\mu \mathrm{g} / \mathrm{mL}$ (Rindiana, 2014). Selanjutnya telah dilakukan juga penelitian lain oleh (Irma,2015) pada ekstrak etil asetat memberikan efek antiinflamasi pada tikus putih (Rattus norvegicus) jantan pada dosis 200 dan $400 \mathrm{mg} / \mathrm{kgBB}$, sedangkan pada ekstrak etanol daun akar kaik-kaik Uncaria cordata (Lour) Merr memberikan efek antiinflamasi pada hewan tikus putih dengan dosis 100, 200 dan $400 \mathrm{mg} / \mathrm{kgBB}$ (Sefralisa, 2015). Selanjutnya penelitian yang dilakukan (Putri,2016) pada ekstrak n-heksan memiliki aktivitas antiinflamasi pada dosis 200 dan $400 \mathrm{mg} / \mathrm{kgBB}$ pada tikus putih jantan.

Penelitian lain terhadap daun tumbuhan akar kaik-kaik ini juga dilakukan oleh (Rahmawati dan Utami,2016) dari penelitian tersebut didapatkan bahwa daun tumbuhan Akar kaik-kaik (Uncaria cordata (Lour) Merr) memiliki aktivitas sebagai sitotoksik dengan senyawa yang diperoleh merupakan senyawa Uc7 golongan terpenoid dan mempunyai aktivitas sitotoksik kategori yang sangat kuat yaitu $2.57 \mu \mathrm{g} / \mathrm{mL}$.

Dalam hal pengembangan obat yang berasal dari alam perlu diketahui efek penggunaan obat-obat tersebut terhadap keamanan di dalam tubuh. Pendekatan penilaian keamanan obat dapat dilakukan dengan uji toksisitas. Pengujian toksisitas yang harus dilakukan meliputi uji toksisitas akut, tertunda, subkronik dan kronik. Untuk melihat efek toksik yang ditimbulkan dari penggunaan ekstrak etanol daun akar kaik-kaik (Uncaria cordata (Lour) Merr) dalam jangka waktu yang singkat perlu dilakukan uji toksisitas akut. Uji toksisitas akut adalah suatu pengujian untuk mendeteksi efek toksik yang muncul dalam waktu yang singkat setelah pemberian sediaan uji yang diberikan secara oral 
dalam dosis tunggal, yang diberikan dalam waktu 24 jam (BPOM RI, 2014).

Pengujian toksisitas akut dilakukan dengan tujuan untuk menentukan nilai $\mathrm{LD}_{50}$ dari ekstrak etanol daun akar kaik-kaik (Uncaria cordata (Lour) Merr) dan melihat efek toksisitas tertunda dalam waktu 14 hari. Adapun parameter yang diamati yaitu perubahan berat badan, volume air minum, volume urin, konsumsi makanan, berat feses, dan rasio organ hati, ginjal, dan jantung. Pengamatan juga dilakukan terhadap adanya gejala terlihat pada hewan uji seperti tremor, kejang, saliva, diare, letargi, lemah, tidur, dan koma (BPOM RI, 2014).

Berdasarkan nilai $\mathrm{LD}_{50}$ yang diperoleh dapat ditentukan kriteria toksisitas yang dilihat berdasarkan tabel klasifikasi tingkat toksisitas, sehingga dapat diperoleh gambaran keamanan dalam pemanfaatan daun akar kaik-kaik (Uncaria cordata (Lour) Merr) sebagai obat berkhasiat bagi masyarakat. Oleh karena itu, peneliti tertarik untuk melakukan uji toksisitas akut dan tertunda dari ekstrak etanol daun akar kaik-kaik (Uncaria cordata (Lour) Merr).

\section{METODOLOGI PENELITIAN}

\section{Alat}

Alat yang digunakan adalah : alat suntik (sonde oral), gelas beker, gelas ukur, kaca arloji, kandang mencit, lumpang, stanfer, pipet tetes, spatula, vial, meja pengamatan, stopwatch, gunting, pinset, dan timbangan hewan.

\section{Bahan}

Bahan yang akan digunakan pada penelitian ini adalah ekstrak etanol daun tumbuhan Akar kaikkaik (Uncaria cordata (Lour) Merr), NaCMC 1\%, mencit putih jantan serta makanan mencit, $\mathrm{HCl}$ Pekat, Klorofom, Klorofom amoniak, Logam Mg, $\mathrm{FeCl}_{3} 1 \%$, $\mathrm{H}_{2} \mathrm{SO}_{4}$ pekat, Asam Asetat anhidrat, Aquadest.

\section{Hewan Percobaan}

Hewan percobaan yang digunakan dalam penelitian ini adalah mencit putih (Mus muculus Ll) jantan yang sehat berumur 2-3 bulan dengan berat rata- rata 20-30 g. Hewan coba dibagi dalam 5 kelompok dengan cara random sampling, sehingga setiap kelompok terdiri dari 5 ekor mencit.

\section{Skrining Fitokimia Infusa}

a. Uji Flavoniod

Beberapa tetes air ditambahkan dengan beberapa tetes $\mathrm{HCl}$ pekat, kemudian ditambahkan 0,2 mg logam $\mathrm{Mg}$. Hasil positif ditunjukkan dengan timbulnya warna jingga, merah muda sampai merah dalam waktu 3 menit.

\section{b. Uji Fenolik}

Beberapa tetes lapisan air dimasukkan ke dalam tabung reaksi, lalu ditambahkan beberapa tetes $\mathrm{FeCl}_{3}$ 1\%. Hasil positif ditunjukkan dengan timbulnya warna ungu sampai biru kehitaman.

\section{c. Uji Saponin}

Beberapa tetes lapisan air dimasukkan ke dalam tabung reaksi, lalu dikocok. Hasil positif ditunjukan dengan timbulnya busa yang stabil.

d. Uji Terpenoid dan Steroid

Lapisan kloroform disaring melalui pipet yang sudah terdapat norit dimana berfungsi untuk menarik pigmen warna, agar mudah untuk mengidentifikasi warna hasil uji. Lalu teteskan pada plat tetes, untuk uji terpenoid lapisan klorofom ditambahkan 1-2 tetes reagen Liberman Buchard (2 tetes asam asetat anhidrat dan 1 tetes asam sulfat pekat) yang menunjukkan hasil positif jika menghasilkan warna merah. Sedangkan untuk uji steroid, lapisan kloroform ditambahkan 1-2 tetes reagen Liberman Bouchard, hasil positif ditunjukkan dengan menghasilkan warna hijau- biru.

e. Uji Alkaloid

Untuk pemeriksaan alkaloid, beberapa gram ekstrak ditambahkan $10 \mathrm{~mL}$ kloroform, kemudian ditambahkan $10 \mathrm{~mL}$ larutan kloroform amoniak 0,05 M, diaduk kemudian disaring, lalu tambahkan $1 \mathrm{~mL}$ asam sulfat 2 $\mathrm{N}$ dimasukkan ke dalam tabung reaksi, dikocok selama 2 menit dibiarkan hingga terbentuk dua lapisan lalu terjadi pemisahan. Diambil lapisan asam (atas) dan ditambahkan 1-2 tetes pereaksi Mayer, hasil positif jika terbentuk endapan putih.

\section{Penentuan Dosis mg/kg BB}

Untuk menentukan jarak antar dosis, digunakan faktor kenaikan dosis dari Malone (Thompson, 1995) :

$$
\begin{aligned}
& F=n-1 \sqrt{ } D B \\
& D n=D K . F
\end{aligned}
$$

Keterangan :

$$
\begin{aligned}
\mathrm{F} & =\text { faktor kelipatan dosis } \\
\mathrm{n} & =\text { jumlah tingkatan dosis yang } \\
& \text { diinginkan } \\
\mathrm{DB}= & \text { cdosis terbesar } \\
\mathrm{DK} & =\text { dosis terkecil } \\
\mathrm{Dn} & =\text { dosis yang akan diberikan }
\end{aligned}
$$

Berdasarkan rumus Malone diatas, factor kelipatan dosis yang diperoleh adalah 5. Sehingga variasi dosis yang digunakan adalah $200 \mathrm{mg} / \mathrm{kgBB}, 1000 \mathrm{mg} / \mathrm{kgBB}$ dan $5000 \mathrm{mg} / \mathrm{kgBB}$.

\section{Pembuatan Sediaan uji}

Volume sediaan uji yang akan diinjeksikan secara oral ke dalam tubuh hewan percobaan adalah maksimal $1 \mathrm{ml}$ (BPOM RI, 2014). Berat zat uji yang akan disuspensikan ditimbang terlebih dahulu berdasarkan konsentrasi dan masing-masing dosis. Konsentrasi zat dihitung dengan menggunakan rumus :

VAO $(\mathrm{ml})=$ Berat Badan $(\mathrm{kg}) \times$ Dosis $(\mathrm{mg} / \mathrm{kg} \mathrm{BB})$

\section{Penyiapan Hewan Percobaan}

$$
\text { Konsentasi (mg/ml) }
$$

Hewan percobaan yang akan digunakan untuk uji toksisitas akut dan tertunda adalah mencit putih (Mus musculus L) jantan muda dewasa yang sehat sebanyak 20 ekor. Umur mencit yang digunakan berkisar antara 5-6 minggu dengan berat badan 20-30 gram.

Hewan percobaan diaklimatisasi selama 7 hari sebelum perlakuan. Kemudian hewan percobaan dipelihara dan dimasukkan ke dalam kandang metabolit. Pada bagian alas kandang diberi kertas saring dan tempat makanan serta untuk tempat minumnya 
diletakkan terpisah.

Mencit jantan yang digunakan untuk penelitian adalah mencit jantan yang dinilai sehat, dengan variasi bobot tidak lebih dari $20 \%$ dan secara visual memperlihatkan prilaku yang normal. Selain itu dipilih juga mencit putih jantan yang belum pernah diberikan perlakuan. Hewan percobaan dikelompokkan menjadi 4 kelompok yang masing-masing kelompok terdiri dari 5 ekor mencit.

\section{Penentuan Nilai LD50}

Nilai $\mathrm{LD}_{50}$ ditentukan dengan menghitung jumlah kematian hewan selama 24 jam akibat pemberian zat uji pada tingkat dosis. Untuk menghitung $\mathrm{LD}_{50}$ berdasarkan Farmakope Indonesia III, uji harus memenuhi syarat-syarat sebagai berikut (Priyanto, 2009);

a. Menggunakan seri dosis atau konsentrasi yang berkelipatan tetap

b. Jumlah hewan percobaan tiap kelompok harus sama

c. Dosis harus diatur sedemikian rupa supaya memberikan respon dari 0-100\% dan hitungan dibatasi direntang tersebut.

Rumus perhitungan $\mathrm{LD}_{50}$ adalah $(\mathrm{Lu}, 2006)$

$$
\mathrm{m}=\mathrm{a}-\mathrm{b}\left(\sum \mathrm{pi}-0,5\right)
$$

$$
\begin{aligned}
& \text { Keterangan : } \\
& \mathrm{m} \quad=\log \mathrm{LD}_{50} \\
& \mathrm{a}=\log \text { dosis terkecil yang masih menyebabkan }
\end{aligned}
$$

$\mathrm{LD}_{50}$ dinyatakan sebagai dosis yang menunjukkan kematian hewan sebanyak $50 \%$ dari jumlah hewan percobaan selama 24 jam setelah penyuntikan.

\section{Analisis Data}

Untuk mendapatkan nilai $\mathrm{LD}_{50}$ data yang diperoleh diolah menggunakan Metoda Farmakope Indonesia. Untuk parameter perubahan, tremor, kejang, salivasi, diare, letargi, lemah, tidur, dan koma data mengunakan analisa secara kuantitatif.

\section{Hasil}

Dari penelitian yang telah dilakukan diperoleh hasil sebagai berikut :

1. Hasil skrining fitokimia

Hasil skrining fitokimia menunjukan bahwa pada ekstrak etanol daun akar kaik-kak (Uncaria cordata (Lour) Merr) terdapat kandungan metabolit sekunder yaitu alkaloid, flavonoid, fenolik, saponin, steroid.

2. Uji Toksisitas Akut

Berdasarkan penelitian hasil uji toksisitas akut tidak ditemukan kematian hewan percobaan pada pemberian dosis 200, 1000, maupun $5000 \mathrm{mg} / \mathrm{kg}$ BB
3. Tidak ditemukannya gejala-gejala toksik seperti tremor, kejang, salivasi, diare, letargi,lemah, tidur, dan koma pada hewan coba, dimana pemeriksaan dilakukan 3 jam setelah pemberian ekstrak etanol daun akar kaik- kaik.

Tabel 1. Jumlah Mencit Jantan yang Mati pada Pengamatan dalam Waktu 24 jam setelah Pemberian Sedian Uji Ekstrak Etanol Daun Akar kaik-kaik.

\begin{tabular}{|c|c|c|c|}
\hline Kelompok & Perlakuan & $\mathrm{n}$ & $\begin{array}{c}\text { Jmlah hewan yang } \\
\text { mati }\end{array}$ \\
\hline I & Kontrol & 5 & 0 \\
\hline II & Dosis $200 \mathrm{mg} / \mathrm{kg} \mathrm{BB}$ & 5 & 0 \\
\hline III & $\begin{array}{c}\text { Dosis } 1000 \mathrm{mg} / \mathrm{kg} \\
\text { BB }\end{array}$ & 5 & 0 \\
\hline IV & $\begin{array}{c}\text { Dosis } 5000 \mathrm{mg} / \mathrm{kg} \\
\text { BB }\end{array}$ & 5 & 0 \\
\hline \multicolumn{3}{|c}{} \\
\hline
\end{tabular}

Keterangan :

$$
\mathrm{n} \text { : Jumlah hewan percobaan }
$$

\section{Pembahasan}

Pada tahap awal penelitian dilakukan identifikasi tumbuhan di Labotorium Botani Fakultas Matematika dan Ilmu Pengetahuan Alam (FMIPA) jurusan Biologi Universitas Riau. Dari hasil identifikasi yang diperoleh, dinyatakan bahwa tumbuhan tersebut adalah tumbuhan akar kaik-kaik dengan nama spesies (Uncaria cordata (Lour) Merr) yang termasuk marga Uncaria. Selanjutnya dilakukan uji skrining fitokimia, uji ini berguna untuk mengetahui senyawa metabolit sekunder dari tanaman. Pendekatan skrining fitokimia meliputi analisis kualitatif kandungan kimia dalam tumbuhan atau bagian tumbuhan seperti kulit, rimpang, umbi, daun, batang, buah dan biji (Marjoni, 2016). Berdasarkan hasil dari uji skrining fitokimia menunjukkan bahwa ekstrak etanol daun tumbuhan akar kaik-kaik (Uncaria cordata (Lour) Merr) mengandung golongan metabolit sekunder antara lain alkaloid, fenolik, saponin, flavonoid, dan steroid. Pada metabolit sekunder alkaloid, fenolik, saponin, flavonoid, dan steroid diduga dapat bersifat toksik pada kadar tertentu.

Kemudian penelitian dilanjutkan dengan pengujian toksisitas akut. Uji toksisitas akut merupakan suatu pengujian yang dilakukan untuk mendeteksi efek toksik yang muncul dalam waktu singkat setelah pemberian sediaan uji yang diberikan dalam dosis tunggal dalam waktu 24 jam (BPOM RI, 2014). Uji toksisitas akut digunakan untuk menetapkan nilai $\mathrm{LD}_{50}$ dari Ekstrak etanol daun akar kaik-kaik.

Dalam pemilihan hewan percobaan dipilih mencit putih jantan yang dinilai sehat dengan kriteria tidak cacat fisik, dan berumur 5-6 minggu, dengan berat badan 20-30 gram. Alasan memilih mencit putih jantan, karena hormonal jantan lebih stabil dibandingkan dengan mencit betina. Yang mana, mencit betina tersebut mengalami masa-masa atrus, kehamilan, dan menyusui. Selain itu, tingkat stres pada mencit putih betina lebih tinggi dibandingkan mencit putih jantan (BPOM RI, 2014). Hewan dikelompokkan secara acak 
sehingga penyebaran berat badan merata untuk semua kelompok dengan variasi berat badan tidak melebihi $20 \%$ dari rata- rata berat badan .

Sebelum pemberian ekstrak etanol daun akar kaik-kaik pada mencit putih jantan, terlebih dahulu disuspensikan dengan NaCMC $1 \%$ b/v, Sebelum penelitian dilakukan, hewan percobaan terlebih dahulu diaklimatisasi selama 7 hari. Hal ini dilakukan untuk menyesuaikan hewan percobaan dengan kondisi lingkungan yang baru. Konsentrasi yang biasanya digunakan untuk sediaan oral dan sediaan dapat terdispersi dengan baik dan homogen. Pemilihan NaCMC sebagai pensuspensi dikarenakan NaCMC menghasilkan suspensi yang stabil, bersifat inert sehingga tidak mempengaruhi zat berkhasiat, tidak toksik dan tidak mengiritasi (Raymond dan Paul, 2003). Suspensi ekstrak etanol daun akar kaik-kaik diberikan secara oral. Pemberian secara oral merupakan jalur pemakaian obat yang umum digunakan dan juga karena cara pemberian diupayakan sesuai dengan cara penggunaannya pada manusia ( $\mathrm{Lu}$, 2006).

Pengamatan dilakukan dengan melihat jumlah kematian hewan percobaan selama 24 jam, waktu dihitung setelah dilakukannya pemberian sediaan uji terhadap hewan percobaan. Dari hasil uji toksisitas akut, setelah diberi perlakuan dengan dosis 200, 1000, dan $5000 \mathrm{mg} / \mathrm{kg} \mathrm{BB}$ tidak ditemukan adanya kematian, sehingga penentuan nilai $\mathrm{LD}_{50}$ pada uji toksisitas akut ini tidak perlu dilakukan untuk dosis yang lebih tinggi (BPOM RI,2014). Hal ini menunjukkan bahwa ekstrak etanol daun akar kaik-kaik memiliki nilai $\mathrm{LD}_{50}>5000$ $\mathrm{mg} / \mathrm{kgBB}$ dan dikategorikan Praktis tidak toksik (Lu, 2006).

Gejala toksik seperti letargi, lemah, tidur, dan koma yang diamati pada setiap hewan percobaan tidak memperlihatkan adanya gejala tersebut. Hal ini juga menunjukkan bahwa pada ekstrak etanol daun akar kaik-kaik tidak memperlihatkan pengaruh pemberian ekstrak terhadap hewan percobaan.

\section{Kesimpulan}

Dari penelitian yang telah dilakukan dapat disimpulkan bahwa :

1. Ekstrak etanol daun akar kaik-kaik (Uncaria cordata (Lour) Merr) mempunyai nilai $\mathrm{LD}_{50}>$ $5000 \mathrm{mg} / \mathrm{kg}$ BB yang dikategorikan praktis tidak toksik.

2. Pengamatan dilakukan setelah 3 jam pemberian sedian uji, selama perlakuan tidak ditemukan adanya tremor, kejang, salivasi, diare, letargi, lemah, tidur, dan koma pada setiap hewan percobaan.

\section{Saran}

Disarankan pada penelitian selanjutnya untuk melakukan penelitian tentang toksisitas subkronik dan kronik dari ekstrak etanol daun akar kaik-kaik (Uncaria cordata (Lour) Merr)terhadap mencit putih (Mus musculus L) jantan.

\section{Daftar Pustaka}

BPOM RI, 2014, Pedoman Uji Toksisitas Nonklinik Secara In Vivo, Departemen Kesehatan Republik Indonesia, Kepala Badan Pengawas Obat dan Makanan, Jakarta.

Djauhariya, E dan Hernani., 2004, Gulma Berkhasiat Obat. Cetakan I. Jakarta: Penebar Swadya.

Ernawati. 2004. Budidaya, Pengolahan Hasil dan Kelayakan Usaha Tani Gambir (Uncaria gambir Roxb.) di Kabupaten 50 Kota. Buletin Penelitian Tanaman Rempah dan Obat : Balitrro

Irma A.K., 2015, Uji Kualitas Dan Aktivitas Antiinflamasi Ekstrak Etil Asetat Daun Tumbuhan Akar kaik-kaik (Uncaria cordata (Lour) Merr) Terhadap Tikus Putih (Rattus Norvegicus) Jantan. Skripsi, Sekolah Tinggi Ilmu Farmasi Riau. Pekanbaru.

Kusumawati, D. 2004. Bersahabat dengan Hewan Coba. Yogyakarta: Gadjah Mada University Press.

Lu, C.F., 2006, Toksikologi Dasar. Universitas Indonesia. Jakarta.

Marjoni, R. 2016. Dasar-Dasar Fitokimia Untuk Diploma III Farmasi. Jakarta: Trans Info Media.

Ndagijimana, A., Xiaoming, W., Yongzhi, H., Guixiang, P., Agyemang, K., Ying, L., 2013. A Riview of The Occurance of (Non- alkoloid Constituens in Uncaria Spesies and Their Structure-activity Relationships American Journal of Biomedical and Life Sciences, 1(4):79-98.

Putri, W. N. A,. 2016. Uji Aktivitas Antiinflamasi Ekstrak $n$-heksan Daun Tumbuhan Akar kaikkaik Uncaria cordata (Lour) Merr Terhadap Tikus Putih (Rattus novegitus) Jantan, Skripsi, STIFAR Pekanbaru.

Rahmawati, N. dan Utami, R. 2016. Isolasi Dan Uji Aktivitas Sitotoksik Senyawa Murni Dari Ekstrak Etil Asetat Daun Tumbuhan Akar kaik-kaik Uncaria cordata ( Lour .) Merr. Scienta, 6(2): 122-126.

Raymond, C.R., dan Paul, S., 2003, Handbook of Pharmaceutical Excipients, Edition IV, Pharmaceutical Press, USA.

Rindiana R., 2014. Isolasi Dan Uji Aktivitas Antioksidan Ekstrak Metanol Daun Akar kaikkaik Uncaria cordata (Lour) Merr. Skripsi, Sekolah Tinggi Ilmu Farmasi Riau. Pekanbaru.

Sefralisa W., 2015. Uji Aktivitas Antiinflamasi Ekstrak Etanol Daun Tumbuhan Akar Kaik- Kaik (Uncaria cordata (Lour) Merr terhadap Tikus Putih (Rattus novergicus) Jantan. Skripsi, Sekolah Tinggi Ilmu Farmasi Riau.

Soewolo. 2010. Pengantar anatomi Fisiologi Hewan. Jakarta : Dirjen Dikti Depdiknas, Jakarta.

Sun G., Zhang X., Xu X., Yang J., Zhong M., dan Yuan J., 2012. A New Triterpen From Uncaria macrophylla and its AntitumorActivity, 
Jurnal Penelitian Farmasi Indonesia 10(2), Desember 2021

ISSN : 2302-187X

e-ISSN 2656-3614

Molecules, 17: 1883-1889.

Thompson, 1995, Farmakope Indonesia Edisi IV. Jakarta: Departemen Kesehatan Republik Indonesia, Jakarta. 448,515, 771, 1000. 